\title{
Our Bizarre System for Proving Copyright Infringement ${ }^{1}$
}

\author{
Mark A. Lemley ${ }^{2}$
}

At the heart of copyright infringement cases is "substantial similarity" between the plaintiff's and the defendant's works. But while every circuit agrees on the centrality of substantial similarity, that basic agreement conceals surprising differences in what exactly we mean by substantial similarity and how it is to be proven in court. And the majority approach, defined by the Second Circuit in Arnstein v. Porter ${ }^{3}$ and the Ninth Circuit in Sid and Marty Krofft, ${ }^{4}$ has the analysis of proof exactly backwards permitting analytic dissection of the works and expert testimony where the question is one that should be handed to the members of the jury, and falling back on the "ordinary observer" test on the very questions that require careful dissection by the court. I argue that the Arnstein and Krofft tests make no sense. A better model draws from software copyright cases, which give filtration and dissection of unprotectable elements a more central role.

\section{The Meaning of Substantial Similarity}

\section{A. The Two "Substantial Similarities"}

1 (C) 2010 Mark A. Lemley.

2 William H. Neukom Professor, Stanford Law School; partner, Durie Tangri LLP. Thanks to Jonathan Band, Megan Gray, Rose Hagan, Jessica Litman, Tyler Ochoa, Mike Page, Fred von Lohmann, members of the Copyright Society in San Francisco, and the Brace Lecture audience in New York for comments on an earlier draft, and to David Rizk for research assistance.

3 Arnstein v. Porter, 154 F.2d 464, 468 (2d Cir. 1946).

4 Sid \& Marty Krofft Television Prods., Inc. v. McDonald's Corp., 562 F.2d 1157, 1164 (9th Cir. 1977). 
Copyright infringement requires, not surprisingly, proof of copying. Sometimes copying is uncontested; the defendant admits she copied the work but claims that that copy was lawful, for example under the fair use doctrine. But in many cases, the battle is over whether the defendant's work is in fact copied from the plaintiff's.

When the question of copying is in dispute, the plaintiff can prove copying by either direct or circumstantial evidence. Direct evidence - the defendant who says "I cannot tell a lie," or the witness who watched the copying occur - is possible, but rare. More commonly, courts will infer unlawful copying by proof of a combination of the defendant's access to the plaintiff's work and what courts call "substantial similarity." ${ }^{5}$ The role of substantial similarity here is probative; the idea is that if the defendant had access to the plaintiff's work and the defendant's work is similar enough to the plaintiff's, the most plausible inference is that the defendant actually copied from the plaintiff. ${ }^{6}$

But copying alone is not illegal. If I copy a single word from a copyrighted book, I have engaged in copying, but I have not engaged in copyright infringement. For copying to rise to the level of infringement, it must include a more than de minimis amount of copyrightable expression. The purpose of this doctrine is to avoid flooding the courts with trivial infringement cases. For as the Second Circuit noted, "[t]rivial copying is a significant part of modern life. Most honest citizens in the world engage, without

5 Selle v. Gibb, 741 F.2d 896, 901 (7 $7^{\text {th }}$ Cir. 1984); Repp v. Lloyd Webber, 132 F.3d 882 (2d Cir. 1997).

6 Indeed, Alan Latman suggests that this analysis be called "probative similarity." Alan Latman, "Probative Similarity" as Proof of Copying: Toward Dispelling Some Myths in Copyright Infringement, 90 Colum. L. Rev. 1187 (1990). Some courts have adopted this language. See, e.g., Laureyssens v. Idea Group, 964 F.2d 131 (2d Cir. 1992). 
hesitation, in trivial copying that, but for the de minimis doctrine, would technically constitute a violation of the law."7 We can think of this second element, beyond proof of copying, as "improper appropriation."

Unfortunately, courts and commentators regularly lump the entire inquiry under the single term "substantial similarity." ${ }^{8}$ This not only makes it confusing to read cases, ${ }^{9}$ but it also leads courts themselves to conflate the two distinct elements. For example, the Eight Circuit in Rottlund Co. v. Pinnacle Corp. spoke of a "two-step" test for substantial similarity. ${ }^{10}$ Rather than distinguish proof of copying from proof that what was copied was unlawful, however, the court viewed the entire inquiry as about substantial similarity, and concluded that what must be shown is similarity both as to ideas and as to expression:

Rottlund argues that the district court erred in admitting Scherer's expert testimony evidence regarding substantial similarity. Determination of substantial similarity involves a two-step analysis under Hartman $v$. Hallmark Cards, Inc., 833 F.2d 117 (8th Cir. 1987). There must be substantial similarity both of ideas and of expression. ${ }^{11}$

7 Davis v. Gap, Inc., 246 F.3d 152, 173 (2d Cir. 2001). See also SMS v. ASP, 560 F.3d 53, 59 (1 ${ }^{\text {st }}$ Cir. 2009); Sandoval v. New Line Cinema Corp., 147 F.3d 215, 217 (2d Cir. 1998) (referring to de minimis copying as "so trivial as to fall below the quantitative threshold of substantial similarity"); Toulmin v. Rike-Kumler Co., 316 F.2d 232 (6 ${ }^{\text {th }}$ Cir. 1963) (copying of less than two sentences from a book "a clear case of de minimis"); Rosemont Ents., Inc. v. Random House, Inc., 366 F.2d 303, 306 (2d Cir. 1966). Paul Goldstein suggests that there should be no de minimis test in copyright, preferring instead to focus on whether the copying attracted the audience away from the plaintiff's work. 2 Goldstein on Copyright $\S 9.3 .1$ at 9-30 to 9-32. But the de minimis principle is well established in the law.

8 See, e.g.,Murray Hill Pubs. v. Twentieth Century Fox Film Corp., 361 F.3d 312, 316-21 (6 ${ }^{\text {th }}$ Cir. 2004); Williams v. Crichton, 84 F.3d 581 (2d Cir. 1996).

9 In the Third Circuit's colorful language, "[w]hile '( $r$ )ose is a rose is a rose is a rose,' substantial similarity is not always substantial similarity." Universal Athletic Sales Co. v. Salkeld, 511 F.2d 904, 907 (3d Cir. 1975).

10452 F.3d at 726, 731 (8th Cir. 2006) (some citations omitted).

11833 F.2d at 120. 
The Ninth Circuit made the same mistake in Sid and Marty Krofft. ${ }^{12}$ This is a particularly odd formulation; a defendant who copies wholesale the plaintiff's protected expression is surely not immunized from copyright infringement because her ideas are different. ${ }^{13}$ And if the court did think ideas rather than expression were relevant evidence of copying, it is not clear why it would be dissecting the work into its component parts at the first stage of the inquiry.

Other courts are misled by the term "substantial similarity" to conflate the two inquiries. For example, the district court in Steinberg v. Columbia Pictures ${ }^{14}$ inquired into whether the movie poster for "Moscow on the Hudson" was an unlawful copy of Saul Steinberg's New Yorker cover "A New Yorker's View of the World." Because the court did not separate the probative similarity and unlawful appropriation inquiries, it spent a substantial portion of its time discussing the similarities of unprotectable elements, such as the stylized font used in the title. ${ }^{15}$ While the court said that copying of unprotectable elements was not itself illegal, its conflation of the two inquiries led it to focus most of its attention on the easy question in that case (the defendant surely did copy from the plaintiff's cover) and elide the hard question of whether the copying was in fact of protectable expression.

12 Sid \& Marty Krofft Television Prods., Inc. v. McDonald's Corp., 562 F.2d 1157, 1164 (9th Cir. 1977) ("But there also must be substantial similarity not only of the general ideas but of the expressions of those ideas as well. Thus two steps in the analytic process are implied by the requirement of substantial similarity.").

13 For example, those who copy expression to mock or parody it might have a fair use defense, but their copying is no less copying because the idea behind it is different.

14663 F. Supp. 706 (S.D.N.Y. 1987).

15 Id. at 


\title{
B. Proof of Copying and Proof of Unlawful Appropriation - Convergence on
}

\author{
the Two-Step Test
}

Notwithstanding the occasional confusion engendered by the term "substantial similarity," many courts have properly separated the two inquiries. Some have done so expressly, speaking of probative similarity and unlawful appropriation. ${ }^{16}$ But the primary tests - the Second and Ninth Circuit formulations - use different terminology that maps to these two different inquiries. Critical in both cases is not so much the question being asked as who evaluates the question and how. The Second Circuit speaks of a two-part inquiry, one involving analysis and dissection and the second involving an "ordinary observer" test. The leading case is Arnstein v. Porter. ${ }^{17}$ Arnstein holds:

... If there is evidence of access and similarities exist, then the trier of fact must determine whether the similarities are sufficient to prove copying. On this issue,

16 Bridgamon v. Array Systems Corp., 325 F.3d 572, 576-77 (5th Cir. 2003):

A copyright infringement claim requires proof of (1) ownership of a valid copyright and (2) actionable copying, which is the copying of constituent elements of the work that are copyrightable. Eng'g Dynamics, Inc. v. Structural Software, Inc., 26 F.3d 1335, 1340 (5th Cir. 1994) (citing Feist Publ'ns, Inc. v. Rural Tel. Serv. Co., 499 U.S. 340, 361 (1991). Two separate inquiries must be made to determine whether actionable copying has occurred. The first question is whether the alleged infringer copied, or "actually used the copyrighted material in his own work." Id. Copying can be proven by direct or circumstantial evidence. Arnstein v. Porter, 154 F.2d 464, 468 (2d Cir. 1946) (Frank, J.). Circumstantial evidence may support an inference of copying if the defendant had access to the copyrighted work and there is "probative similarity" between the copyrighted work and the allegedly infringing work. Eng'g Dynamics, Inc., 26 F.3d at 1340.

Accord Laureyssens v. Idea Group, 964 F.2d 131 (2d Cir. 1992); Johnson v. Gordon, 409 F.3d 12 (1 $1^{\text {st }}$ Cir. 2005).

17 Arnstein v. Porter, 154 F.2d 464, 468 (2d Cir. 1946). It is worth noting that the result in Arnstein - to reverse summary judgment to defendant Cole Porter on Arnstein's claim that Porter hired "stooges" to follow him around and steal his songs - seems crazy. Arnstein was a serial litigant who sued any number of famous musicians alleging copying. See, e.g., Arnstein v. Edward B. Marks Music Corp., 82 F.2d 275 (2d Cir. _); Arnstein v. Broadcast Music, 137 F.2d 410 (2d Cir. _). 
analysis ("dissection") is relevant, and the testimony of experts may be received to aid the trier of fact.

If copying is established, then only does there arise the second issue, that of illicit copying (unlawful appropriation). On that issue (as noted more in detail below) the test is the response of the ordinary lay hearer; accordingly, on that issue, "dissection" and expert testimony are irrelevant. ${ }^{18}$

The Second's more recent cases have affirmed this basic approach to infringement analysis. $^{19}$

The Ninth Circuit takes the same basic two-step approach, though it refers to "extrinsic" and "intrinsic" analyses for the probative similarity and unlawful appropriation steps respectively. Curiously, though, the Ninth Circuit, like the Eighth, refers to the question of probative similarity - similarity from which a factfinder can infer copying - as the similarity of ideas. Krofft reads in relevant part:

... But there also must be substantial similarity not only of the general ideas but of the expressions of those ideas as well. Thus two steps in the analytic process are implied by the requirement of substantial similarity.

The determination of whether there is substantial similarity in ideas may often be a simple one....

We shall call this the 'extrinsic test.' It is extrinsic because it depends not on the responses of the trier of fact, but on specific criteria which can be listed and analyzed. Such criteria include the type of artwork involved, the materials used, the subject matter, and the setting for the subject. Since it is an extrinsic test, analytic dissection and expert testimony are appropriate. Moreover, this question may often be decided as a matter of law.

The determination of when there is substantial similarity between the forms of expression is necessarily more subtle and complex....

The test to be applied in determining whether there is substantial similarity in expressions shall be labeled an intrinsic one depending on the response of the ordinary reasonable person. It is intrinsic because it does not depend on the

18 Arnstein v. Porter, supra.

19 See, e.g., Ringgold v. BET, 126 F.3d 70 (2d Cir. 1997); Laureyssens v. Idea Group, 964 F.2d 131 (2d Cir. 1992); Walker v. Time Life Films, Inc., 784 F.2d 44, 51-52 (2d Cir. 1986). But cf. Castle Rock Entertainment v. Carol Pub'l Group, 150 F.3d 132 (2d Cir. 1998) (holding that the ordinary observer test did not work well in the case of a trivia book about the TV show Seinfeld, because the works were of such different types). 
type of external criteria and analysis which marks the extrinsic test. As this court stated in Twentieth Century-Fox Film Corp v. Stonesifer, 140 F.2d 579, 582 (9th Cir. 1944):

'The two works involved in this appeal should be considered and tested, not hypercritically or with meticulous scrutiny, but by the observations and impressions of the average reasonable reader and spectator.' Because this is an intrinsic test, analytic dissection and expert testimony are not appropriate." 20

Thus, the Ninth Circuit limits the first query - the one on which expert testimony and analytic dissection is appropriate - to a consideration of "substantial similarity" of ideas, and the (holistic) second analysis to a consideration of the relative similarity of "expression" only. Subsequent cases have revised Krofft so that the first step now considers the similarity of both ideas and expression, ${ }^{21}$ but they have left the analysis of improper appropriation in step two to the jury considering the works as a whole.

Other circuits have generally lined up with either the Arnstein or the Krofft formulation. The First Circuit follows Arnstein and the "ordinary observer test":

The ordinary observer test was incorporated by the Second Circuit, in Arnstein v. Porter, 154 F.2d 464 (2d. Cir. 1946), as the second step in a two part test for copyright infringement. Pursuant to that test, the court first must determine whether there has been "copying." Id. at 468. This step involves "dissection" of the work, perhaps aided by expert testimony, to assess whether there are sufficient articulable similarities to justify a finding that the defendant has copied from the protected work. Id. Second, once "copying" is established, the court must determine whether the copying is sufficiently substantial to constitute "unlawful appropriation" ("illicit copying"). Id. That is, copying only trivial aspects of another's work will not result in substantial similarity; it is only when the copying is sufficiently extensive that infringement occurs. Under this second step of the analysis, therefore, the trier of fact applies the "ordinary observer" test, unaided by dissection or expert testimony,

20 Sid \& Marty Krofft Television Prods., Inc. v. McDonald's Corp., 562 F.2d 1157, 1164 (9th Cir. 1977).

21 Shaw v. Lindheim, 919 F.2d 1353, 1357 (9th Cir. 1990). 
to determine whether the copying resulted in substantial similarity between the works. $I d .^{22}$

The First Circuit uses the ordinary observer, not expert testimony, to determine the critical issue of unlawful appropriation:

The test is whether the accused work is so similar to the plaintiff's work that an ordinary reasonable person would conclude that the defendant unlawfully appropriated the plaintiff's protected expression by taking material of substance and value." ... ${ }^{23}$

The Third Circuit similarly follows Arnstein and emphasizes the irrelevance of expert

testimony to the ultimate legal conclusion:

To establish a copyright infringement, the holder must first prove that the defendant has copied the protected work and, second, that there is a substantial similarity between the two works. The criterion for the latter requirement is whether an ordinary lay observer would detect a substantial similarity between the works. ...

But, substantial similarity to show that the original work has been copied is not the same as substantial similarity to prove infringement. As the Arnstein case points out, dissection and expert testimony in the former setting are proper but are irrelevant when the issue turns to unlawful appropriation. ${ }^{24}$

The circuits that do not follow Arnstein generally line up behind the Ninth Circuit's Krofft test, which differs from the Second Circuit test in its focus on the comparison of ideas as well as expression, but takes the same basic two-step procedural approach, admitting expert testimony on the factual question of copying but not on the ultimate question of unlawful appropriation. Krofft itself refers to the difference as being between similarity of ideas and similarity of expression, but that is neither the

22 See Concrete Machinery Co., Inc. v. Classic Lawn Ornaments, Inc., 843 F.2d 600, 608-09 (1st Cir. 1988).

23 Yankee Candle Co., Inc. v. Bridgewater Candle Co., LLC, 259 F.3d 25, 33-34 (1st Cir. 2001); Johnson v. Gordon, 409 F.3d 12 ( $1^{\text {st }}$ Cir. 2005).

24 Universal Athletic Sales Co. v. Salkeld, 511 F.2d 904, 907 (3d Cir. 1975). 
right question to ask nor the one the court actually seems to ask in subsequent cases. ${ }^{25}$

The primary difference between the two tests in practice seems to be that the Ninth Circuit puts more emphasis than the Second on the ordinary observer side of the analysis - what it calls the "intrinsic" inquiry. Thus, the court in Roth Greeting Cards gives the fundamental question of "look and feel" directly to the finder of fact. ${ }^{26}$ So has the Fifth Circuit. ${ }^{27}$ And the Ninth Circuit has reversed district courts that allowed experts to testify on the question of the significance of musical similarities, ${ }^{28}$ as has the Federal Circuit when applying Ninth Circuit law to furniture design. ${ }^{29}$ The Fourth, $^{30}$ Sixth, $^{31}$ and Eleventh $^{32}$ Circuits have adopted the Krofft formulation of the test. The Eighth Circuit

25 See, e.g., Aliotti v. R. Dakin \& Co., 831 F.2d 898 ( $9^{\text {th }}$ Cir. 1987); Shaw v. Lindheim, 919 F.2d 1353 ( $9^{\text {th }}$ Cir. 1990); Rice v. Fox Broadcasting Corp., 330 F.3d 1170 ( $9^{\text {th }}$ Cir. 2003).

26 Roth Greeting Cards v. United Card Co., 429 F.2d 1106 ( $9^{\text {th }}$ Cir. 1970). It is perhaps worth noting that the Roth case was tried to the court, not a jury.

27 Positive Black Talk Inc. v. Cash Money Records Inc., 394 F.3d 357, 374 (5 ${ }^{\text {th }}$ Cir. 2004).

28 Swirsky v. Carey, 376 F.3d 841 ( $9^{\text {th }}$ Cir. 2004).

29 Amini Innovation v. Anthony California, 439 F.3d 1365 (Fed. Cir. 2006).

30 Dawson v. Hinshaw Music Inc. 905 F.2d 731, 732-36 (4th Cir. 1990). Accord Lyons

Partnership, L.P. v. Morris Costumes, Inc., 243 F.3d 789, 801 (4th Cir. 2001).

31 See Stromback v. New Line Cinema, 384 F.3d 283, 293-95 (6th Cir. 2004).

32 The Eleventh Circuit accepted Krofft in Herzog. See Herzog v. Castle Rock Entertainment, 193

F.3d 1241, 1257 (11th Cir. 1999):

Under the extrinsic test, a court will inquire into whether, as an objective matter, the works are substantially similar in protected expression. As a part of this test, a court will determine whether a plaintiff seeks to protect only uncopyrightable elements; if so, the court will grant summary judgment for defendant. Under the extrinsic test, expert testimony and analytic dissection are appropriate. Under the intrinsic test, a court will determine whether, upon proper instruction, a reasonable jury would find that the works are substantially similar. A court may grant summary judgment for defendant as a matter of law if the similarity between the two works concerns only noncopyrightable elements of the plaintiff's work or if no reasonable jury would find that the two works are substantially similar.

However, the court has also recognized the Arnstein two-part framework for infringement analysis, wherein the "ordinary observer" perspective applies to the misappropriation inquiry. Leigh v. Warner Bros., Inc., 212 F.3d 1210, 1214 (11th Cir. 2000) ("The plaintiff can prove copying either directly or indirectly, by establishing that the defendant had access, and produced something 'substantially similar,' to the copyrighted work. ... Substantial similarity, in 
seems to follow both Arnstein's ordinary observer test and Krofft, rejecting expert testimony on the issue of unlawful appropriation. ${ }^{33}$

\section{Outliers on Expert Testimony}

The general convergence on a two-step approach has translated into a widespread approach that permits expert testimony in the first step - inferring copying - but excludes it when it comes to the second step of determining whether that copying is unlawful. ${ }^{34}$ Most of the circuits we have discussed adopt this general approach, whether they cite Arnstein or Krofft, though as we will see it is sometimes tempered in cases in which the "ordinary observer" is a specialized buyer with knowledge the jury might not have.

this sense, 'exists where an average lay observer would recognize the alleged copy as having been appropriated from the copyrighted work'"). Accord Lil' Joe Wein Music, Inc. v. Jackson, 245 Fed. Appx. 873, 877 (11th Cir. 2007). See also Oravec v. Sunny isles Luxury Ventures, L.C., 527 F.3d 1218, 1224 n.5 (11th Cir. 2008) (criticizing Herzog).

33 Hartman v. Hallmark Cards, Inc., 833 F.2d 117, 120 (8th Cir. 1987) (expert opinion is admissible on question of actual copying or copying of ideas; analytical dissection is inappropriate when analyzing substantial similarity of expression); Rottlund Co. v. Pinnacle Corp., 452 F.3d at 726, 731 (8th Cir. 2006) (some citations omitted):

Expert opinion and analytical dissection are not appropriate to establish or rebut similarity of expression. ... Rather, "substantial similarity of expression is measured by the response of the ordinary, reasonable person to the forms of expression."

34 While a few circuits mistakenly refer to that as a distinction between "copying of facts" and "copying of expression," see supra, in fact similarities of ideas, facts, and expression can all be evidence from which a factfinder could infer that the defendant in fact copied from the plaintiff. 
A few circuits adopt the two-step analysis but diverge from the consensus on expert testimony, however. On the one hand, the Sixth Circuit applies a higher standard than most for purposes of admitting expert testimony on the first prong:

Subsequent to the district court's opinion and order granting summary judgment and dismissing the case, this court adopted a two-part test in Kohus $v$. Mariol, 328 F.3d 848 (6th Cir. 2003), which follows the test employed by the D.C. Circuit in Sturdza v. United Arab Emirates, 281 F.3d 1287 (D.C. Cir. 2002). We stated that "the first step 'requires identifying which aspects of the artist's work, if any, are protectible by copyright,' [and] the second 'involves determining whether the allegedly infringing work is "substantially similar" to protectible elements of the artist's work.' " Kohus, 328 F.3d at 855 (quoting Sturdza). This test is really just a refinement of the ordinary observer test that, as its initial step, parses from the work the elements neither afforded copyright protection nor properly considered in the ordinary observer test. "The essence of the first step is to filter out the unoriginal, unprotectible elements-elements that were not independently created by the inventor, and that possess no minimal degree of creativity, through a variety of analyses." Id. (citation omitted). Our test is similar to the Ninth Circuit's test, because the first part, like the Ninth Circuit's extrinsic test, requires a determination of only the expressive elements of a work, while the second part, like the Ninth Circuit's intrinsic test, asks whether the ordinary, reasonable observer would find the works, taken as a whole, to be substantially similar. ...

However, significant differences remain in both parts. ...

Our test "appl[ies] a more stringent standard regarding when to allow expert testimony on the first part of the test." Murral Hill Publ'ns, Inc., 361 F.3d at 318. We remanded in Kohus in part because the copyright involved a latch for a portable children's play yard, and we thought that expert testimony would be necessary to determine whether certain elements of such a latch should be excluded from the substantial similarity analysis. See Kohus, 328 F.3d at 856. Whether expert testimony should be allowed in a particular case remains a matter committed to the discretion of the trial court under Federal Rule of Evidence 702 if such testimony "will assist the trier of fact to understand the evidence or to determine a fact in issue." However, where, as here, the subject matter is not complex or technical, such as a computer program or a functional object, see, e.g., Gates Rubber Co. v. Bando Chem. Indus., Ltd., 9 F.3d 823, 83435 (10th Cir. 1993) (noting that in most cases involving computer programs expert testimony will be helpful to the court in applying an abstractions test), but 
instead involves a literary work aimed at a general audience, expert testimony will seldom be necessary to determine substantial similarity. ${ }^{35}$

On the other side, the Seventh Circuit, which nominally follows the Arnstein test, seems more open to expert testimony on both the inference of copying and the lawfulness of the appropriation. In Atari, the court adopted the "ordinary observer" language, but diverged from the majority treatment of expert testimony:

Some courts have expressed the test of substantial similarity in two parts: (1) whether the defendant copied from the plaintiff's work and (2) whether the copying, if proven, went so far as to constitute an improper appropriation. See ... Arnstein v. Porter, 154 F.2d 464, 468 (2d Cir. 1946); cf. Sid \& Marty Krofft Television Productions, Inc. v. McDonald's Corp., 562 F.2d 464, 468 (9th Cir. 1977) (extrinsic-intrinsic test). Our analysis focuses on the second part of that test and the response of the "ordinary observer." ... Specifically, the test is whether the accused work is so similar to the plaintiff's work that an ordinary reasonable person would conclude that the defendant unlawfully appropriated the plaintiff's protectible expression by taking material of substance and value. Krofft, 562 F.2d at 1164. Judge Learned Hand, in finding infringement, once stated that "the ordinary observer, unless he set out to detect the disparities, would be disposed to overlook them, and regard their aesthetic appeal as the same." It has been said that this test does not involve "analytic dissection and expert testimony," Arnstein, 154 F.2d at 468, but depends on whether the accused work has captured the "total concept and feel" of the copyrighted work.

While dissection is generally disfavored, the ordinary observer test, in application, must take into account that the copyright laws preclude appropriation of only those elements of the work that are protected by the copyright. "It is an axiom of copyright law that the protection granted to a copyrightable work extends only to the particular expression of an idea and never to the idea itself." ${ }^{36}$

35 See Stromback v. New Line Cinema, 384 F.3d 283, 293-95 (6th Cir. 2004); accord Murray Hill Pub'Ins, Inc., v. Twentieth Century Fox Film Corp., 361 F.3d 312, 318 (6th Cir. 2004) ("we apply a more stringent standard [than the Ninth Circuit] regarding when to allow expert testimony on the first part of the test").

36 Atari, Inc. v. North American Phillips Consumer Electric Corp., 672 F.2d 607, 614-15 (7th Cir. 1982). 
In other cases, the Seventh Circuit appears to have validated expert testimony on the

question of improper appropriation on at least one occasion:

The jury's access finding is further supported by the striking similarity between the LMT head and Sirko's doll head that provided the basis for Drummer. See Ty, 132 F.3d at 1170. This court applies the "ordinary observer" test to determine whether a substantial similarity existed between the two dolls' heads. Wildlife Express, 18 F.3d at 508-09. The inquiry under this test is "whether the accused work is so similar to the plaintiff's work that an ordinary reasonable person would conclude that the defendant unlawfully appropriated the plaintiff's protectible expression by taking material of substance and value." Id. at 509 (quoting Atari, 672 F.2d at 614). Because the works at issue deal with the reproduction of a lifelike object - a toddler - Wakeen must prove that Drummer is substantially similar "to those few aspects of the work that are expression not required by the idea." Wildlife Express, 18 F.3d at 508.

The "idea" in this case was a depiction of a toddler's face. The artistic "expression" of LMT according to Wakeen was an idealized child's face that reflected the essence of a baby's beauty and innocence. Wakeen presented demonstrative exhibits and expert testimony at trial that supported the jury's factual determination that LMT and Drummer were substantially similar. The jury compared the two heads themselves, saw photographs of the two heads, examined porcelains of the heads, and looked at an LMT head with Drummer hair in order to assess the similarities between the two works. In addition, the jury heard testimony from Singer, Wakeen's expert, saying that the two heads' facial features were virtually identical. ${ }^{37}$

The First Circuit seems implicitly to follow the Seventh, since it has found expert

testimony admissible even once copying has been proven:

In determining what aspects of the Yankee labels are protected under copyright law, we follow essentially the same path as did the district court. We first "dissect" the work to remove those aspects not protected by copyright. Despite Yankee's argument to the contrary, this Court has indicated that dissection analysis is an appropriate method of evaluating substantial similarity even when actual copying has occurred. "By dissecting the accused work and identifying those features which are protected ... [t] ] court can also determine ... those aspects of the work that ... should be considered in the ... comparative analysis under the ordinary observer test." Concrete Mach., 843 F.2d at $609 . . .{ }^{38}$

37 Susan Wakeen Doll, Inc. v. Ashton Drake Galleries, 272 F.3d 441, 451 (7th Cir. 2001).

38 Yankee Candle Co., Inc. v. Bridgewater Candle Co., LLC, 259 F.3d 25, 33-34 (1st Cir. 2001). 


\section{Who is an "Ordinary" Observer?}

While the circuits have largely converged on the two-step test, there are subtle differences in how courts apply that test. One difference is that the courts that follow Krofft are more willing to treat as the "ordinary observer" the likely customer of the copyrighted products, which may or may not be a member of the jury. The Fourth Circuit has discussed the matter at length in Dawson v. Hinshaw Music Inc.:

As correctly noted by the district court, there are two prongs to the substantial similarity inquiry. The plaintiff must establish substantial similarity of both the ideas of the two works and of the expression of those ideas. Litchfield, 736 F.2d at 1356. It is well established that expert testimony is admissible for proof under the first prong which courts have referred to as an "extrinsic" or "objective" inquiry. See id. The district court accordingly admitted expert testimony on Dawson's proof that the idea of Martin's work was substantially similar to the idea of Dawson's work. ...

Although Arnstein established a sound foundation for the appeal to audience reaction, its reference to "lay listeners" may have fostered the development of a rule that has come to be stated too broadly. Under the facts before it, with a popular composition at issue, the Arnstein court appropriately perceived "lay listeners" and the works' "audience" to be the same. However, under Arnstein's sound logic, the lay listeners are relevant only because they comprise the relevant audience. Although Arnstein does not address the question directly, we read the case's logic to require that where the intended audience is significantly more specialized than the pool of lay listeners, the reaction of the intended audience would be the relevant inquiry. In light of the copyright law's purpose of protecting a creator's market, we think it sensible to embrace Arnstein's command that the ultimate comparison of the works at issue be oriented towards the works' intended audience.

Our reading of Arnstein brings our analysis into line with Sid \& Marty Krofft Television v. McDonald's Corp., 652 F.2d 1157 (9th Cir. 1977), another landmark case involving questions of substantial similarity. ...

Under the foregoing logic, we state the law to be as follows. When conducting the second prong of the substantial similarity inquiry, a district court must consider the nature of the intended audience of the plaintiff's work. If, as will most often be the case, the lay public fairly represents the intended audience, the court should apply the lay observer formulation of the ordinary observer test. However, if the intended audience is more narrow in that it possesses specialized expertise, relevant to the purchasing decision, that lay people would lack, the court's inquiry should focus on whether a member of the 
intended audience would find the two works to be substantially similar. Such an inquiry may include, and no doubt in many cases will require, admission of testimony from members of the intended audience or, possibly, from those who possess expertise with reference to the tastes and perceptions of the intended audience. $^{39}$

Thus, courts following Krofft, both in the Ninth Circuit and outside, apply the ordinary observer test rather than relying on expert testimony on the topic of similarity itself, but treat the intended member of the audience rather than any given member of the public as the "ordinary" observer. ${ }^{40}$ This sometimes influences the use of expert testimony even in circuits, such as the Sixth, which ordinarily reject it:

In cases where the target audience possesses specialized expertise, however, the specialist's perception of similarity may be much different from the lay observer's, and it is appropriate in such cases to consider similarity from the specialist's perspective. The larger principle here is that the inquiry in the second prong of the substantial similarity test should focus on the intended audience. ... This will ordinarily be the lay public, in which case the finder of fact's judgment should be from the perspective of the lay observer or, as Monogram Models put it, the ordinary reasonable person. But in cases where the audience for the work possesses specialized expertise that is relevant to the purchasing decision and lacking in the lay observer, the trier of fact should make the substantial similarity determination from the perspective of the intended audience. Expert testimony will usually be necessary to educate the trier of fact in those elements for which the specialist will look. ${ }^{41}$

It is not clear exactly what works fall into what we might call the "extraordinary observer" category. The Ninth Circuit applied it to video games; the ordinary observer there was "a discerning 17.5-year-old boy". ${ }^{42}$ The Fourth Circuit has found that it might

39905 F.2d 731, 732-36 (4th Cir. 1990). Accord Lyons Partnership, L.P. v. Morris Costumes, Inc., 243 F.3d 789, 801 (4th Cir. 2001).

40 See also Data East USA, Inc. v. Epyx, Inc., 862 F.2d 204 ( $9^{\text {th }}$ Cir. 1988)

41 Kohus v. Mariol, 328 F.3d 848, 857 (6th Cir. 2003).

42 Data East, 862 F.2d at 
apply to some musical works, ${ }^{43}$ though the Second Circuit in Arnstein did not apply it to music. $^{44}$ The Sixth Circuit did not apply the test to musical works, modifying the basic framework for music sampling cases involving fragmented literal similarity, but giving the question of similarity to the jury even where the similarity in songs was the single word "dog" coupled with panting. ${ }^{45}$ The Ninth Circuit has rejected specialized observers for music, concluding that any person untrained in music can understand the differences in note structure. ${ }^{46}$ And the D.C. Circuit has questioned, though not resolved, whether different observers should apply to architectural works. ${ }^{47}$

\section{E. Minimal Protection and the Limits of Substantial Similarity}

One significant substantive departure from the ordinary two-step framework occurs in cases where the copyrightable expression is minimal. A work that lacks any expression, or in which what expression exists has merged with the idea, is not

\footnotetext{
${ }^{43}$ See Dawson v. Hinshaw Music Inc., 905 F.2d 731, 736-38 (4th Cir. 1990) (remanding the issue of whether a choral arrangement of a public domain song should be judged by a lay observer or under a specialized observer test). See also Sergiu Gherman, Harmony and its Functionality: A Gloss on the Substantial Similarity Test in Music Copyrights, 19 Fordham Intell. Prop., Med. \& Ent. L.J. 483, 485, 513-15 (2009) (arguing for the filtration of basic harmony from music copyright cases, and suggesting that the jury is unlikely to be able to apply the test easily); Cadwell, supra note __, at 162-63 (same).

44 Arnstein v. Porter, 154 F.2d 464, 468 (2d Cir. 1946)..

45 Bridgeport Music v. UMG Recordings, 585 F.3d 267 ( th $^{\text {th }}$ Cir. 2009). See also Austin Padgett, The Rhetoric of Predictablity: Reclaiming the Lay Ear in Music Copyright Infringement Litigation, 7 Pierce L. Rev. 125, 146-47 (2008) (arguing against using specialized observers in the analysis of music cases).

46 Swirsky v. Carey, 376 F.3d 841 ( $9^{\text {th }}$ Cir. 2004).

47 See Sturdza v. United Arab Emirates, 281 F.3d 1287, 1300-01 (D.C. Cir. 2002). Cf. Victoria Elman, From the Runway to the Courtroom: How Substantial Similarity Is Unfit for Fashion, 30 Cardozo L. Rev. 683, 687 (2008) (arguing that if Congress adopts copyright-like protection for fashion, it should tailor the substantial similarity test to that industry).
} 
protectable at all. ${ }^{48}$ But works that have only "thin" expression, such as databases that compile unprotectable facts but include creativity in the selection or arrangement of that data, are still entitled to copyright protection. Courts and commentators have, however, recognized that application of the ordinary substantial similarity framework to thin works can be problematic. ${ }^{49}$ As a result, both the Second and Ninth Circuits apply a modified framework to those works: infringement can be found only if the works are "virtually identical" rather than merely substantially similar. ${ }^{50}$ Still other courts, particularly in the Second Circuit, have tried to reach the same result by applying a standard of substantial similarity but having a "more discerning observer" apply the test. $^{51}$

But just as "substantial similarity" combines two different concepts, "virtual identity" alone doesn't tell us whether what the court is asking is "did the defendant copy?" or "is what the defendant took copyrightable?" or both. The Second Circuit appears to be willing to extend its analytic dissection from evidence of copying to evidence of unlawful appropriation in cases of thin protection, replacing the ordinary observer test:

In most cases, the test for "substantial similarity" is the so-called "ordinary observer test" which the district court applied: whether "an average lay observer would [ ] recognize the alleged copy as having been appropriated from the copyrighted work." ...

48 Morissey v. Procter \& Gamble, 379 F.2d 675 ( $1^{\text {st }}$ Cir. 1967).

49 See, e.g., 2 Paul Goldstein, Goldstein on Copyright §9.1.2, at 9:4 ("From a policy perspective, the hardest case is the one in which the defendant's work reflects only structural similarities to the plaintiff's ...").

50 Hoehling v. Universal City Studios, 618 F.2d 972 (2d Cir. 1980), Apple Computer v. Microsoft Corp., 35 F.3d 1435, 1443 ( $9^{\text {th }}$ Cir. 1994).

51 See, e.g.,_Boisson v. Banian, Ltd., 273 F.3d 262, 271 (2d Cir. 2001). 
However, as Lollytogs notes, where we compare products that contain both protectible and unprotectible elements, our inspection must be "more discerning"; we must attempt to extract the unprotectible elements from our consideration and ask whether the protectible elements, standing alone, are substantially similar. ...

Lollytogs contends that the district court erred in comparing the sweaters through the traditional "ordinary observer" test rather than through the "more discerning" test. Instead of comparing the sweater designs as a whole, Lollytogs contends, the court should have "extracted the unprotectible elements"-namely, the use of common stripes and colors-and compared only the sweaters' distinctive elements, i.e., their placement of leaves, squirrels, and other "original" elements. Viewed without their common background elements, Lollytogs urges, the sweaters' designs appear substantially dis-similar, as distinctions among their details, such as the fabric, outlines, and placement of the leaves, become apparent. ${ }^{52}$ [The court rejected that argument, finding that only similarities, not points of dissimilarity, mattered].

The First Circuit suggested in dictum in Yankee Candle that it might apply the same approach:

There may be a qualification to the dissection test of some importance in certain cases. In Knitwaves, Inc. v. Lollytogs, Ltd., 71 F.3d 996, 1003 (2d Cir. 1995), the Second Circuit suggested that the dissection test may not fully resolve the legal issues where the copyright holder claims that the copyrighted material is essentially a host of uncopyrightable individual elements that have been arranged in a unique way that qualifies them for copyright protection. Cf. Feist, 499 U.S. at 362 (copyright available for compilations of unprotectible facts). This Court, however, has been more enthusiastic than the Second Circuit about the use of dissection analysis to disaggregate a visual work into its component elements for the purpose of removing the unprotectible elements contained within.

At any rate, we do not necessarily reject this qualification but think that it has no direct application here. ${ }^{53}$

The Ninth Circuit applied the virtual identity test in Apple v. Microsoft, dissecting the work in step one in order to find the protectable elements so that in step two it might "decide whether the work is entitled to "broad" or "thin" protection. Depending on the

52 Knitwaves, Inc. v. Lollytogs Ltd., 71 F.3d 996, 1002-03 (2d Cir. 1995).

53 Yankee Candle Co., Inc. v. Bridgewater Candle Co., LLC, 259 F.3d 25, 33-34 (1st Cir. 2001). 
degree of protection, the court must set the appropriate standard for a subjective comparison of the works to determine whether, as a whole, they are sufficiently similar to support a finding of illicit copying." ${ }^{54}$ The court didn't reach the issue of expert testimony, however, because Apple conceded that it could not prove virtual identity. Similarly, Satava v. Lowry dissected the elements in step one, found thin copyright protection, and therefore applied the virtual identity standard to deny infringement, but did not specifically rule on whether expert testimony was appropriate in the latter inquiry. ${ }^{55}$ And in Mattel v. MGA Entertainment, the Ninth Circuit held that virtual identity applied to a claim that the maker of Bratz dolls had copied the concept and design from Mattel. ${ }^{56}$

It seems, therefore, that at least in some circuits, including the ones that have led the way in developing infringement standards, courts not only require a higher threshold of proof before finding infringement of a thin copyright but will permit expert testimony on the issue of improper appropriation in those cases. The Sixth Circuit, by contrast, was unwilling to depart from the ordinary observer test in a case that involved the copying of extremely small portions of creative works. ${ }^{57}$

\section{F. The Special Case of Software}

Finally, software cases diverge significantly from the ordinary two-step analysis. Virtually all the courts considering infringement of computer code have permitted

54 Apple Computer v. Microsoft Corp., 35 F.3d 1435, 1443 ( $9^{\text {th }}$ Cir. 1994).

55323 F.3d 805, 808-13 (9 $9^{\text {th }}$ Cir. 2003).

562010 WL 2853761 ( $9^{\text {th }}$ Cir. July 22, 2010).

57 Bridgeport Music v. UMG Recordings, 585 F.3d 267 ( $6^{\text {th }}$ Cir. 2009). 
expert testimony as to both the issue of copying and the issue of improper appropriation. The leading case is Computer Associates v. Altai:

...we recognize the reality that computer programs are likely to be somewhat impenetrable by lay observers-whether they be judges or juries-and, thus, seem to fall outside the category of works contemplated by those who engineered the Arnstein test.

...In making its finding on substantial similarity with respect to computer programs, we believe that the trier of fact need not be limited by the strictures of its own lay perspective. Rather, we leave it to the discretion of the district court to decide to what extent, if any, expert opinion, regarding the highly technical nature of computer programs, is warranted in a given case.

In so holding, we do not intend to disturb the traditional role of lay observers in judging substantial similarity in copyright cases that involve the aesthetic arts, such as music, visual works or literature. ${ }^{58}$

Altai also adopted the "abstraction-filtration-comparison" framework for evaluating substantial similarity; ${ }^{59}$ more on that below. Similarly, the Ninth Circuit has expanded the role of expert testimony to cover "substantial similarity" of expression as well as ideas (again in the copying context), and suggested that analytic dissection may also be relevant to the question of protectability in software cases:

Today, however, the extrinsic test looks at more than just the similarity of ideas. As the district court understood, the extrinsic analysis is "'an objective test which rests upon specific criteria that can be listed and analyzed.'" The extrinsic test thus has become an "objective ... analys[is] of expression."...

... Under the reformulated extrinsic test, we mean to perpetuate "analytic dissection" as a tool for comparing not only ideas but also expression. Thus, it was not error for the district court to use "analytic dissection" in comparing the expressions of the two programs....

The district court's analytic dissection of the five groups of features involving unprotected or unprotectable work was also proper, but for an entirely different reason. This analysis had nothing to do with assessing substantial similarity, and therefore was not subject to the old limitations Krofft imposed on the use of analytic dissection. Instead, as to these groups, the district court applied analytic

58 Computer Associates Intern., Inc. v. Altai, Inc., 982 F.2d 693, 713-14 (2d Cir. 1992) (citations omitted).

59 Id. at 706. 
dissection for the purpose of determining "whether similarities [between the programs] result from unprotectable [or unprotected] expression." ...

This point bears emphasis. Analytic dissection is relevant not only to the copying element of a copyright infringement claim, but also to the claim's ownership element. $^{60}$

The Fifth and Tenth Circuits have also adopted the Altai abstraction-filtration-

comparison test that permits the use of expert testimony in software cases. ${ }^{61}$ Even the

60 Brown Bag Software v. Symantec Corp., 960 F.2d 1465, 1475-76 (9th Cir. 1992).

61 See Eng'g Dynamics, Inc. v. Structural Software, Inc., 26 F.3d 1335, 1342-43 (5th Cir. 1994):

Generally, we endorse the abstraction-filtration-comparison method of determining copyright protection for computer programs, which has been ably elucidated by the Tenth Circuit in Gates Rubber, 9 F.3d 823, 834 (10th Cir. 1993).

The Fifth Circuit does not appear to have considered the question of expert testimony's precise applicability, however.

The Tenth Circuit also uses the "abstraction-filtration-comparison" test, and admits expert testimony concerning abstraction. See Gates Rubber Co. v. Bando Chemical Industries, Ltd., 9 F.3d 823, 834-36 (10th Cir. 1993).

First, in order to provide a framework for analysis, we conclude that a court should dissect the program according to its varying levels of generality as provided in the abstractions test. Second, poised with this framework, the court should examine each level of abstraction in order to filter out those elements of the program which are unprotectable. Filtration should eliminate from comparison the unprotectable elements of ideas, processes, facts, public domain information, merger material, scenes a faire material, and other unprotectable elements suggested by the particular facts of the program under examination. Third, the court should then compare the remaining protectable elements with the allegedly infringing program to determine whether the defendants have misappropriated substantial elements of the plaintiff's program....

The abstractions test is especially well suited to the dissection of computer programs because the test breaks down a program in a way that parallels the typical development of a program....

Application of the abstractions test will necessarily vary from case-to-case and program-to-program. Given the complexity and ever-changing nature of computer technology, we decline to set forth any strict methodology for the abstraction of computer programs. See generally Andrew H. Rosen, Virtual Reality: Copyrightable Subject Matter and the Scope of Judicial Protection, 33 Jurimetrics J. 35 (1992). Indeed, in most cases we foresee that the use of experts will provide substantial guidance to the court in applying an abstractions test. However, a computer program can often be parsed into at least six levels of generally declining abstraction: (i) the main purpose, (ii) the program structure or architecture, (iii) modules, (iv) algorithms and data structures, (v) source code, and (vi) object code...

These generalized levels of abstraction will not, of course, fit all computer codes. Ordinarily, expert testimony will be helpful to organize a particular program into various levels of abstraction. In any event, as pointed out earlier, the organization of a program 
Third Circuit, which is the outlier in the substantive protection of software copyright,

protecting the broad "look and feel" of computer code, nonetheless acknowledges that doing so must rely on expert testimony:

The district court heard expert testimony. It did not bifurcate its analysis, however, but made only a single finding of substantial similarity. It would thus appear to have contravened the law of this circuit. Nevertheless, for the reasons that follow, we believe that the district court applied an appropriate standard.

The ordinary observer test, which was developed in cases involving novels, plays, and paintings, and which does not permit expert testimony, is of doubtful value in cases involving computer programs on account of the programs' complexity and unfamiliarity to most members of the public. Moreover, the distinction between the two parts of the Arnstein test may be of doubtful value when the finder of fact is the same person for each step: that person has been exposed to expert evidence in the first step, yet she or he is supposed to ignore or "forget" that evidence in analyzing the problem under the second step. Especially in complex cases, we doubt that the "forgetting" can be effective when the expert testimony is essential to even the most fundamental understanding of the objects in question.

On account of these problems with the standard, we believe that the ordinary observer test is not useful and is potentially misleading when the subjects of the copyright are particularly complex, such as computer programs. We therefore join the growing number of courts which do not apply the ordinary observer test in copyright cases involving exceptionally difficult materials, like computer programs, but instead adopt a single substantial similarity inquiry according to which both lay and expert testimony would be admissible. ${ }^{62}$

into abstraction levels is not an end in itself, but it is only a tool that facilitates the critical next step of filtering out unprotectable elements of the program.

Accord Autoskill Inc. v. Nat'l Educational Support Sys., Inc., 994 F.2d 1476, 1492-93 (10th Cir. 1993) ("We are convinced that the record furnishes an ample factual basis for the trial judge's analysis on the levels of abstraction and his conclusions as to which were idea levels not entitled to protection, and which were in the expression area and possibly eligible for protection after filtration analysis. There was detailed testimony by Autoskill's expert... As the judge noted, the experts' opinions may be helpful, but their legal conclusions on these points are not binding. The consideration of the experts' views on these matters in drawing the judge's conclusions was within his discretion and not error.")

62 Whelan Assocs., Inc. v. Jaslow Dental Lab., Inc., 797 F.2d 1222, 1232-33 (3d Cir. 1986) (citations omitted). 
Some courts seem to have adopted this framework, or at least the filtration piece of it, in the context of other specialized works such as architecture. ${ }^{63}$

\section{Legal Questions, Factual Inferences, and Experts}

\section{A. The Problems With Arnstein-Krofft}

The basic framework for copyright infringement analysis, then, seems wellestablished. We can infer copying from similarity - in some circuits similarity of expression, in others, at least sometimes, similarity of ideas. In doing so, we will dissect the defendant's work into pieces and consider only the protectable pieces in deciding whether the defendant copied the plaintiff's expression. Expert testimony can be used to dissect the protectable from the unprotectable, as well as to guide the drawing of inferences from different sorts of similarities. But once we have inferred copying, the question of whether that copying is unlawful - legally, whether the copying was of more than a de minimis amount of protectable expression - is a question that is resolved by the jury acting as an ordinary observer, without the benefit of expert testimony.

This basic framework is exactly backwards. To show infringement, at the end of the day the plaintiff must prove that the defendant copied a more than de minimis amount of protectable expression from the plaintiff. If the factual question is "did the defendant in fact copy from the plaintiff," evidence of similarities can be quite probative of copying whether those similarities are of protectable expression or of unprotectable

63 See, e.g., Tiseo Architects Inc. v. B\&B Pools Serv. \& Supply Co., 495 F.3d 344 (6 ${ }^{\text {th }}$ Cir. 2007). 
ideas or elements. ${ }^{64}$ For example, in Feist v. Rural, the plaintiff detected copying of its white pages directory by adding fake name and number listings. ${ }^{65}$ Those fake listings are not copyrightable, so their copying cannot give rise to copyright liability. ${ }^{66}$ But they are surely powerful evidence that the defendant did in fact copy its work from the plaintiff. Similarly, the stylized font common to both Saul Steinberg's "New Yorker's View of the World" and the "Moscow on the Hudson" poster was not itself copyrightable, but the fact that both posters used the same unusual font bolstered the plaintiff's claim of copying.

In short, where the question is probative similarity, there is no reason to think that only similarities of protectable expression can be probative of copying. For the same reason, probative similarity doesn't seem a logical place to employ expert testimony to filter protectable from unprotectable elements. That is not to say expert testimony can never be useful here. Experts may be necessary to assess basic questions of similarity with complex technologies like software, where the jury may be unable to distinguish similarities caused by copying from similarities caused by the way software works. And expert testimony can be useful where the issue is one of merger or scenes a faire, because the jury may need to be educated about the likelihood that particular similarities result from standard approaches to a work and therefore don't constitute strong evidence that the defendant copied from the plaintiff. But the basic question we

\footnotetext{
64 Latman, supra note _, at 1188.

65 Feist Pubs. v. Rural Tel. Serv., 499 U.S. 340 (1991).

66 Even constructed facts are treated as facts by the courts, and so as unprotectable. See, e.g., Urantia Found. v. Maaherra, 114 F.3d 955 ( $9^{\text {th }}$ Cir. 1997); Alan L. Durham, Speaking of the World: Fact, Opinion, and the Originality Standard of Copyright, 33 Ariz. St. L.J. 791 (2001). For criticism of this approach, see Justin Hughes, Created Facts, 83 Notre Dame L. Rev. 43 (2007).
} 
are asking - does the similarity between the two works lead you to believe that the defendant must have copied from the plaintiff despite his denials - seems perfectly suited to a jury.

By contrast, the second stage of the infringement inquiry - whether the defendant copied a more than de minimis amount of material that was in fact legally protected - does require analytic dissection of the work and expert testimony in the vast majority of cases. Judges and juries may be entitled to infer copying from the similarity of fonts in two posters, for example, but they are not entitled to find the defendant liable on that basis, because the font itself is not copyrightable. ${ }^{67}$ The same is true of ideas, necessary incidents of ideas, facts, methods of operation, functional elements, scenes a faire, utilitarian design elements, and elements dictated by necessity. ${ }^{68}$ Juries are unlikely to understand on their own either the fact that these things are excluded or what elements fall into which category. While in theory jury instructions can instruct jurors to exclude all these elements, in practice jurors aren't going to know what things are, for example, scenes a faire in the music industry without some testimony on standard chord progressions. As the Second Circuit noted in Warner Bros. Inc. v. American Broadcasting Companies, Inc., "[t]he 'substantial similarity' that supports an inference of copying sufficient to establish infringement of a copyright is not a concept familiar to the public at large. It is a term to be used in a courtroom to

67 Fonts are generally not copyrightable, see Darden v. Peters, 488 F.3d 277 (4 ${ }^{\text {th }}$ Cir. 2007), though the computer code that implements a font is.

6817 U.S.C. § 102(b); Baker v. Selden, 101 U.S. 99 (1879); Lotus Dev. Corp. v. Borland Int'I, 49 F.3d 807 ( $1^{\text {st }}$ Cir. 1995); Pamela Samuelson, Why Copyright Law Excludes Systems and Processes From the Scope of Its Protection, 85 Tex. L. Rev. 1921 (2007). 
strike a delicate balance between the protection to which authors are entitled under an act of Congress and the freedom that exists for all others to create their works outside the area protected against infringement." ${ }^{\prime 9}$ The improper appropriation prong absolutely requires analytic dissection of the work, and often requires expert testimony to facilitate that dissection. Unfortunately, under the Arnstein-Krofft standard, neither expert testimony nor dissection of the work is possible.

The pernicious effect of Arnstein-Krofft is threefold. The first problem is the inability of the parties to use expert testimony on these "ordinary observer" issues. In many modern cases, the legal issue is not whether the defendant copied from the plaintiff but whether what they copied was in fact legally protected. This was the issue in Mattel, for example, where the designer of the Bratz dolls worked from the originals and included some similarities, but also important differences. It was the issue in Steinberg, where it was virtually impossible for Columbia Pictures to deny that they worked from Steinberg's poster, ${ }^{70}$ and in Rogers $v$. Koons, where artist Jeff Koons admitted designing his color sculpture "String of Puppies" after the plaintiff's black and white photograph of a couple holding eight puppies. ${ }^{71}$ And it is the issue in the Obey Giant case, where Shepherd Fairey concedes that he designed the Obama Hope poster using an AP photograph. ${ }^{72}$ The real question in each of these cases was not whether there was copying, but whether what the defendant took was illegal. But a strict

\footnotetext{
720 F.2d 231, 245 (2d Cir. 1983).

Steinberg v. Columbia Pictures, 663 F. Supp. 706 (S.D.N.Y. 1987).

1960 F.2d 301 (2d Cir. 1991).

72 The reader may want to know that I once represented Shepherd Fairey and Obey Giant in this case, but no longer do.
} 
application of Arnstein-Krofft means that in any case in which copying is admitted, expert testimony should be entirely inadmissible, since the only remaining question is improper appropriation, which is to be judged by the ordinary observer (or perhaps the "more discerning" observer) without the benefit of expert testimony.

This leads to the second problem. Without the benefit of expert testimony and the ability to dissect the work, judges and juries are more likely to find infringement in dubious circumstances, because they aren't properly educated on the difference between protectable and unprotectable elements. ${ }^{73}$ Courts that apply an ordinary observer test are more likely to find infringement using a broad "look and feel" test. One example is Krofft itself, in which the court concluded that McDonald's "McDonaldland" life-size human cartoon characters infringed the "H.R. Pufnstuf" TV show, which also used life-size human cartoon characters, albeit different ones. Another example is Roth Greeting Cards. There, the court found very simple greeting card language such as "I wuv you" copyrighted and infringed by similar but not identical cards. ${ }^{74}$ World of Wonder's successful copyright claim over the movements of the Teddy Ruxpin doll rests on an ordinary observer analysis of similarities; ${ }^{75}$ a court that truly filtered out the unprotectable expression likely would not have found that a tape that controlled Teddy's movements violated the copyright in the original doll. Bratz is arguably another example. There is good reason to believe that the similarities between the dolls in that case result from ideas or scenes a faire, not unlawful copying.

73 See Ann Bartow, Copyrights and Creative Copying, 1 U. Ottawa L. \& Tech. J. 77 (2003) (suggesting that this has been the result).

74 Roth Greeting Cards v. United Card Co., 429 F.2d 1106 ( $9^{\text {th }}$ Cir. 1970).

75 World of Wonder v. Vector Intercontinental, 1986 WL 15608 (N.D. Ohio Dec. 31, 1986). 
But with the dolls merely handed to the factfinder under the ordinary observer test, the limitations of copyright law can easily end up being given short shrift. ${ }^{76}$ And if the problem is bad when judges are making the gestalt judgment, it is even worse with juries, who don't have the experience judges do with disregarding facts they are told are legally irrelevant.

And this in turn brings us to the third problem: a jury-decided "ordinary observer" test is not easily amenable to judicial review, either on JMOL or on appeal. What the ordinary observer might think will also be hard to resolve on summary judgment. Without dissection of the works, it is difficult to know whether the copying the defendant engaged in was in fact legally permissible copying of ideas or unprotectable elements or unlawful appropriation of protected expression.

\section{B. Possible Solutions}

How might we undo the problems caused by the Arnstein-Krofft test? One solution is simply to reverse the "intrinsic" and "extrinsic" components of the test. If we think expert testimony and analytic dissection belong in the improper appropriation prong, but not the probative similarity prong, we could simply do the opposite of what

76 The Ninth Circuit reversed the finding of infringement because it concluded that the higher "virtual identity" standard should apply to the constrained expression in these works. Mattel v. MGA Enterntainment, 2010 WL 2853761 ( $9^{\text {th }}$ Cir. July 22, 2010). While that decision is probably a step in the right direction, at the end of the day it leaves the underlying problem unaddressed. On remand, the jury is presumably to do the same thing - apply the ordinary observer test to the works as a whole. They simply must find a higher degree of similarity. 
we do now. ${ }^{77}$ Doing so would be an improvement over the current system. But it has its own problems. First, as noted above, there are some circumstances in which we want expert testimony on the issue of probative similarity too, particularly where juries might not even recognize a similarity or might not understand why the apparent similarity is in fact probative. Second, whenever expert testimony is allowed for one purpose but forbidden for another, we run the risk that juries will not understand the distinction and will disregard it, using the expert testimony for the impermissible purpose. Finally, the fact that almost every circuit has adopted some version of the Arnstein-Krofft test means that it would be difficult to persuade courts to do exactly the opposite. While the Supreme Court presumably could do so, the absence of a circuit split makes it unlikely the Court will take the issue.

A second solution is to simply expand the role of analytic dissection and expert testimony to both prongs of the substantial similarity analysis. While there is some risk that juries will mistakenly dissect on the first prong and therefore wrongly fail to find probative similarity, that risk is probably fairly minor. Allowing experts on both issues will solve the problem of jury disregard just noted. And because essentially every circuit already permits expert testimony on both issues in software cases under the rubric of the "filtration" analysis, there may be a clearer path to modifying the law. Indeed, the First, Second, Ninth, and D.C. Circuits have all raised the possibility of using expert

77 For an argument that that is precisely what we should do in music copyright cases, see Jeffrey Cadwell, Expert Testimony, Scenes a Faire, and Tonal Music: A (Not So) New Test for Infringement, 46 Santa Clara L. Rev. 137, 158 (2005); Alice J. Kim, Expert Testimony and Substantial Similarity: Facing the Music in (Music) Copyright Infringement Cases, 19 Colum.-VLA J. L. \& Arts 109, 112 (1995). 
testimony and analytic dissection on improper appropriation in non-software cases, though only the First Circuit has gone beyond dictum or speculation and actually applied the rule. ${ }^{78}$ The First Circuit's statement in Yankee Candle that

Despite Yankee's argument to the contrary, this Court has indicated that dissection analysis is an appropriate method of evaluating substantial similarity even when actual copying has occurred. "By dissecting the accused work and identifying those features which are protected ... [t]he court can also determine ... those aspects of the work that ... should be considered in the ... comparative analysis under the ordinary observer test." 79

seems to provide a useful guide for moving toward the even-handed admission of expert testimony.

Finally, it is worth considering whether the dissection of the unprotectable elements of a copyrighted work, and therefore the assessment of whether the defendant's copying was of protectable expression, ought to be a question of law rather than fact. ${ }^{80}$ The line between idea and expression, and the corresponding lines separating facts, functional elements, and the like from copyrightable expression, are

78 Brown Bag Software v. Symantec Corp., 960 F.2d 1465, 1474 n.3 (9th Cir. 1992) (acknowledging that Ninth Circuit law "appears to be moving toward the test favored by Judge Sneed in his separate concurrence in which lay and expert testimony are uniformly admissible."); Warner Bros. Inc. v. American Broadcasting Companies, Inc., 720 F.2d 231, 245 (2d Cir. 1983) ("We need not and do not decide whether survey evidence of the sort tendered in this case would be admissible to aid a jury in resolving a claim of substantial similarity that lies within the range of reasonable factual dispute"). Sturdza v. United Arab Emirates, 281 F.3d 1287, 1300-01 (D.C. Cir. 2002) (refusing to decide admissibility of expert evidence in an architectural works case).

79 Yankee Candle Co., Inc. v. Bridgewater Candle Co., LLC, 259 F.3d 25, 33-34 (1st Cir. 2001).

80 For discussion of this issue, see Lotus Dev. Corp. v. Borland Int'l, 788 F. Supp. 78, 95-96 (D. Mass. 1992), rev'd, 49 F.3d 807 ( $1^{\text {st }}$ Cir. 1995). 
extraordinarily difficult lines to draw. ${ }^{81}$ It is far from clear that juries can do that linedrawing justice, even with the aid of expert testimony and jury instructions telling them to do so. We might be better served by a rule that gives to the jury the basic question of whether the defendant copied, which might or might not involve expert testimony, but reserves the question of whether the copying was unlawful for the court. That seems to be the practical import of the abstraction-filtration-comparison test used in software cases. Doing so will likely result in greater attention to the limiting doctrines of copyright law. And because it will require written opinions, it will also facilitate review of those judgments on appeal.

\section{Conclusion}

Our rules for proving copyright infringement make little sense. They give short shrift to what should be the most important question in many cases - not whether the defendant copied, but whether their copying was unlawful. That question should perhaps be reserved for the courts, but if it is to be given to the jury, it should be given to a jury that is equipped with the tools it needs to answer the question.

81 See, e.g., Nichols v. Universal Pictures Corp., 45 F.2d 119, 121 (2d Cir. 1930); Brandir Int'l, Inc. v. Cascade Pac. Lumber Co., 834 F.2d 1142 (2d Cir. 1987); Carol Barnhart Inc. v. Economy Cover Corp., 773 F.2d 411, 415-18, 420 (2d Cir. 1985). 